\title{
DEVELOPMENT OF A GARLIC BULB SEPARATOR: 2. GRADING UNIT
}

\section{A. M. DRESS ${ }^{(1)}$}

\author{
M. M. IBRAHIM (2)
}

\section{ABSTRACT}

Grading unit is the second operation in garlic bulb separator; with a separated clove grading is necessary to further processing. A grading and cleaning unit was added to garlic bulb separator. The grading unit was developed through consecutive stages of design, fabrication and evaluation. Some physical and mechanical properties (dimensions, mass, volume, static coefficient of friction and terminal velocity) of garlic bulb that are pertinent to the mechanical processing were measured and considered in design stage of grading unit.

The developed unit was evaluated at four levels of crank speed $\left(C_{S}\right)(200$, 225, 250 and $275 \mathrm{rpm})$, four levels of feeding rate $\left(F_{R}\right)(233,266,326$ and $\left.353 \mathrm{~kg} \mathrm{~h}^{-1}\right)$ and three levels of sieve angle ( $\left.S_{A}\right)$ (5, 10 and $20 \mathrm{deg}$.). The Evaluation was based on the following parameters: grading efficiency $(G E)$, machine capacity $\left(P_{m}\right)$, consumed energy $(C E)$ and cost. The results recommend operating the machine at combinations of $C_{S}$ $=225 \rightarrow 250 \mathrm{rpm}, S_{A}=5 \rightarrow 20$ degrees at different $F_{R}$ to maximize GE value of $86.9 \%-97.8 \%$. The grading unit capacity increased to about 2.7 times and the grading cost decreased to about $93 \%$ comparing with manual method. The obtained results were used to introduce empirical equations to predict the values of " $P_{m}, G E$ and $C E$ " as a function of " $C_{S}$, $F_{R}$ and $S_{A}{ }^{\prime \prime}$.

Keywords: Garlic, grading, design, cleaning, consumed energy, sieve.

\section{INTRODUCTION}

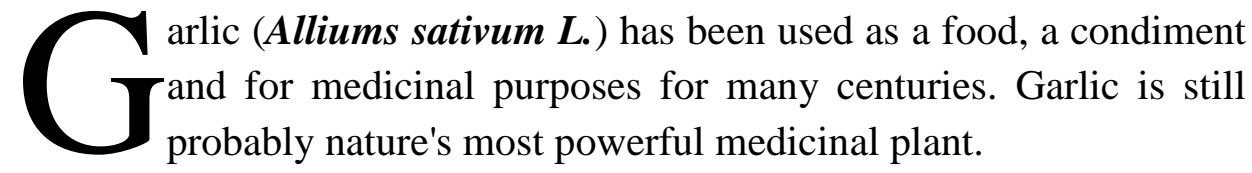
Garlic does not produce seeds, so it must be propagated vegetatively with garlic cloves as the most common planting material. The yield quality of garlic is affected by planting methods and clove rates and sizes (Nourai, 1994; Matlob and Khalel, 1986).

(1) Assoc. Prof., Ag. Eng. Dept., Fac. of Agric., AL-Azhar University- Assuit. (2) Assist. Prof., Ag. Eng. Dept., Fac. of Agric., Cairo University. 
Castellanos et al. (2004) reported the direct influence of garlic seed size on yield and the quality of the harvested bulb. The biggest seeds produced more vigorous plants with greater leaf area and large bulb diameters.

Klenin et al. (1985) stated that the agricultural product is cleaned and graded according to various criteria governing each material. These criteria are: geometric size of each particle, their aerodynamic properties, the shape and state of the surface, density and specific weight, electric conductivity and color.

Nigrini et al. (1994) mentioned that the vibratory seed cleaner is considered as an efficient apparatus to achieve clean and grader small seeds of higher quality.

Amin (2003) mentioned that the sieving time, cell shape, and oscillating speed were the main factors that affected the separation efficiency. This efficiency increased by increasing sieving time and oscillating speed.

Before planting, bulbs must be separated into individual cloves. Grading is a second operation in garlic production, the manual grading consumed time and is labour intensive operation.

The objective of the present work was to develop grading and cleaning units to be added to separating unit and introduce a combine garlic bulb separator.

\section{MATERIALS AND METHODS}

\subsection{Sample preparation}

Garlic bulbs (Egyptian Baladi variety) were randomly collected from different farms. Similar to local practice, the bulbs were dried by spreading in a thin-layer inside a darkroom with open windows near the farms for 15 days. Samples were stored in cool room at $5^{\circ} \mathrm{C}$.

The sample bulbs were randomly selected from the bulk sample and the outer shell was manually peeled before experiments. The moisture content of garlic was determined by following ASAE S352.2 (ASAE 1999) standard. 


\subsection{Physical and mechanical properties of garlic cloves}

The following physical and mechanical properties of garlic cloves that are pertinent to the mechanical processing were measured and considered in the design of the grading unit.

\subsubsection{Dimensions, mass and volume of garlic cloves}

Some physical properties of garlic cloves that are pertinent to the mechanical processing, determined by Bahnasawy (2007), were considered by the design and the development of the machine. The properties that were used are presented in Table (1).

Table (1): Some physical properties of garlic cloves ${ }^{(1)}$.

\begin{tabular}{lccc}
\hline & \multicolumn{3}{c}{ Bulb size $^{(2)}$} \\
\cline { 2 - 4 } & Small & Medium & Large \\
\hline Length $(\mathrm{mm})$ & 19.2 & 24.1 & 29.1 \\
Width $(\mathrm{mm})$ & 7.8 & 9.3 & 13.2 \\
Thickness $(\mathrm{mm})$ & 6.9 & 7.3 & 9.9 \\
mass $(\mathrm{g})$ & 0.67 & 1.12 & 2.40 \\
Volume $\left(\mathrm{cm}^{3}\right)^{(3)}$ & 2.12 & 4.39 & 6.19 \\
\hline
\end{tabular}

(1) Mean values of the properties.

(2) The bulb size graded into three categories according to the Egyptian Organization of Controlling the Export Standard, $\{<40 \mathrm{~mm}$ (small), from 40 to $60 \mathrm{~mm}$ (medium) and $>60 \mathrm{~mm}$ (large) $\}$.

(3) Volume was determined by the researchers.

\subsubsection{Coefficient of static friction}

Coefficient of static friction is the ratio of force required to start sliding the sample over a surface divided by the normal force (Halling, 1975). The static coefficient of friction of garlic cloves against different materials, namely plywood, Galvanized metal and rubber was determined at moisture content value of $70.3 \%$. The device was used for the determination of the coefficient of static friction as shown in figure (1) according to Ibrahim, (2008).

The static coefficient of friction was calculated as follows:

$$
\mu=\frac{F_{T}-F_{E}}{W}
$$


Where

$\mu \quad$ : Coefficient of static friction.

$\mathrm{F}_{\mathrm{T}} \quad$ : $\quad$ Force required to start motion of filled wooden frame $(\mathrm{N})$.

$\mathrm{F}_{\mathrm{E}} \quad$ : Force required to start motion of empty wooden frame $(\mathrm{N})$.

W : Weight of the object $(\mathrm{N})$.

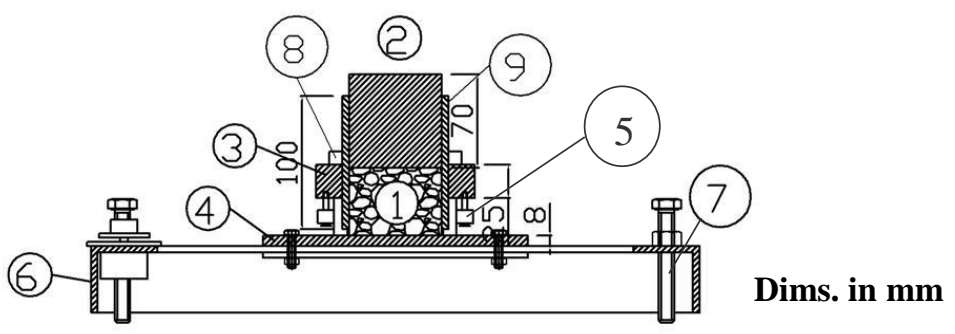

1-Sample

4- Sliding surface

2- Piston

7- Adjustable screw

5- Rolling wheels

3- Carriage

8- Adjustable nut

6- Base

Fig. (1): The device for measuring the friction force.

\subsubsection{Terminal velocity}

The terminal velocities of leaves and garlic clove samples were measured by using an air column (Tabak and Wolf 1998); (similar to Awady and Sayed, 1994). The air inlet pipe of the fan has a circular shape $90 \mathrm{~mm}$ diameter, the outlet of the fan has a rectangular shape $8 \times 11 \mathrm{~cm}$, to control the amount of air. A movable gate (a circular pieces of paper) was placed on the inlet pipe of the fan. The gate area was adjusted to give variable air velocities. The air velocity was measured using tri-Sence digital instrument connected with a velocity probe, (range from 0.1 to 25 $\mathrm{m} \mathrm{s}^{-1}$, its accuracy $0.1 \mathrm{~m} \mathrm{~s}^{-1}$ ).

The mechanical properties of the garlic cloves (Egyptian Baladi variety) are presented in Table (2). They were considered in the design and the development of the machine.

Table (2): Some mechanical properties of garlic cloves.

\begin{tabular}{llcccc}
\hline Property & & Min. & Max. & Mean & Stand. Dev. \\
\hline \multirow{2}{*}{$\begin{array}{l}\text { Coefficient of } \\
\text { friction }\end{array}$} & Metal & 0.38 & 0.71 & 0.45 & 0.08 \\
& Wood & 0.37 & 0.78 & 0.40 & 0.09 \\
\hline $\begin{array}{l}\text { Terminal velocity }\left(\mathrm{m} \mathrm{s}^{-1}\right) \\
\quad \text { Garlic cloves }\end{array}$ & 0.44 & 0.79 & 0.56 & 0.12 \\
$\quad$ Chaff & 12.12 & 17.50 & 14.52 & 0.24 \\
\hline
\end{tabular}




\subsection{Design of grading and cleaning components}

The geometrical characteristics and aerodynamic properties of the garlic cloves are considered for effective grading and cleaning units in the design of the machine. The grading and cleaning units were designed and fabricated as shown in Fig. (2).

The grading and cleaning unit was added to the garlic separator machine to obtain garlic cloves as graded and clean to use as a seed. This unit consists of two different sieves of different opening sizes and a centrifugal fan.

\subsubsection{Sieve unit}

The sieve unit is composed of screen, crank mechanism and power transmission.

\subsubsection{Screen characteristics}

Screens are characterised by parameters such as hole shape and the coefficient of opening (Co).

The axial dimension of garlic cloves was used to calculate the estimated average sphericity as suggested by Mohsenin (1986).

$$
\mathrm{S}_{\mathrm{ph}}=\mathrm{D}_{\mathrm{g}} / \mathrm{L}
$$

Where

$\mathrm{S}_{\mathrm{ph}}:$ : Sphericity.

$\mathrm{Dg} \quad: \quad$ Geometric mean diameter $(D g=\sqrt[3]{L W T})$.

Sphericity of garlic clove ranged from $48.89 \%$ to $53.64 \%$. So the materials have low sphericity. An oblong shape screen must be used according to Okunola and Igbeka (2009).

The garlic cloves were thus divided into three grades: large, medium, and small. Sieve openings with 6-7 - and $8 \mathrm{~mm}$ diameters were determined. The sieve consists of two sieves; the upper one is used for separating the large cloves. The second sieve is used for separating the medium cloves. The lower sheet is to collect the small cloves. The proper mesh-size of the sieves was determined from physical properties of garlic cloves (Table 1). The sizes of the screen are $25 \times 10 \mathrm{~mm}$ (upper screen) and 20 $\times 8 \mathrm{~mm}$ (lower screen). 

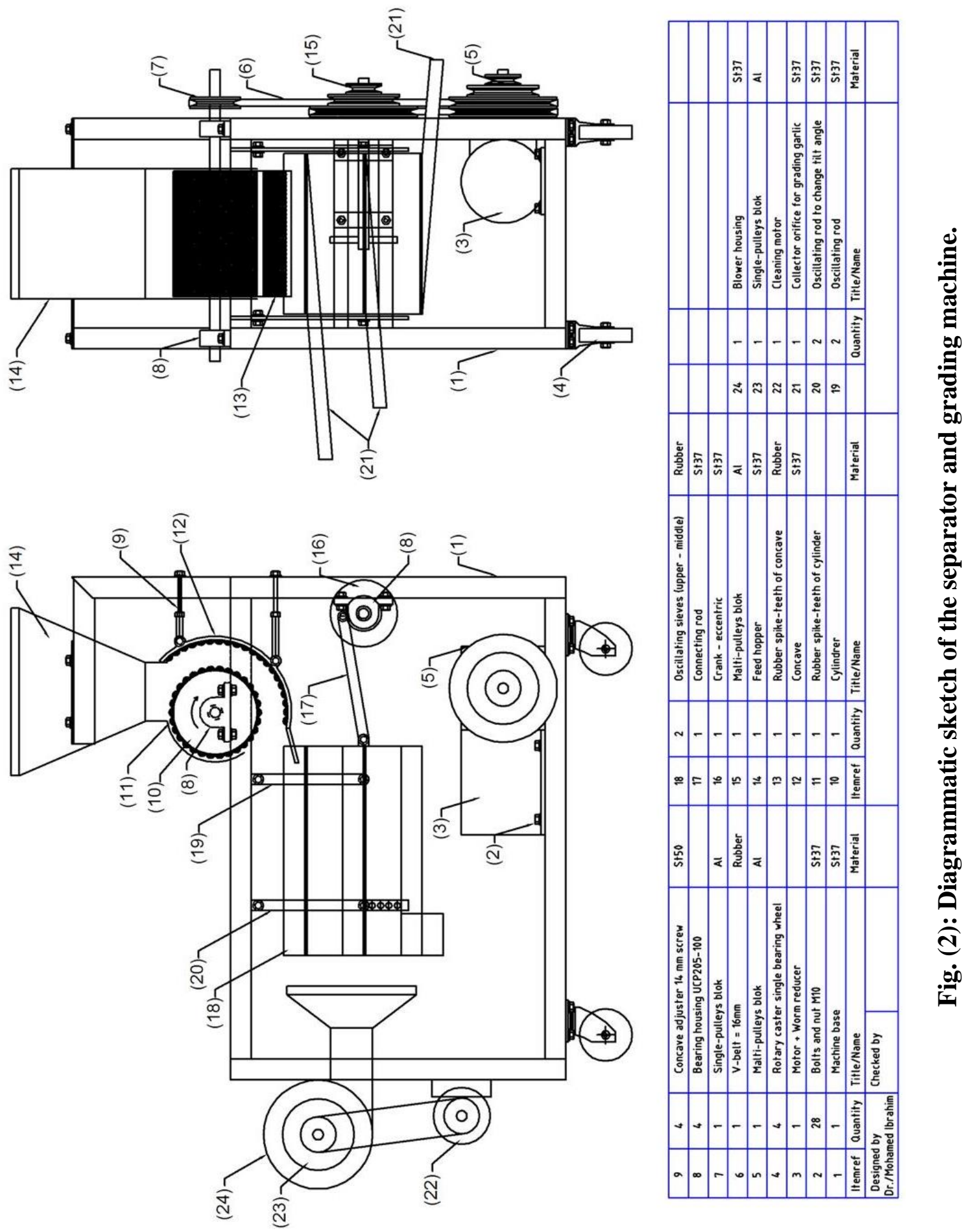
For efficient screening, coefficient of opening (Co) was calculated by applying the following equation and was found to be taken as $40 \%$ according to Okunola and Igbeka (2009). It can calculated the (Co) for oblong opening as follows (Fig. 3):

$$
C o=\frac{\text { Open area }}{\text { Total area }}=\frac{L_{s} W_{s}}{\left(L_{s}+d_{2}+\frac{d_{2}}{n_{2}}\right)\left(W_{s}+d_{1}+\frac{d_{1}}{n_{1}}\right)} \times 100
$$

Where

$\mathrm{L}_{\mathrm{s}} \quad$ : Length of opening $(\mathrm{mm})$.

$\mathrm{W}_{\mathrm{s}}$ : Width of opening $(\mathrm{mm})$.

$\mathrm{d}_{1, \mathrm{~d}_{2}}$ : Distance between adjacent lateral and elongated sides ( $\mathrm{mm}$ ).

$\mathrm{n}_{1}, \mathrm{n}_{2}:$ Number of holes in the lateral and elongated side

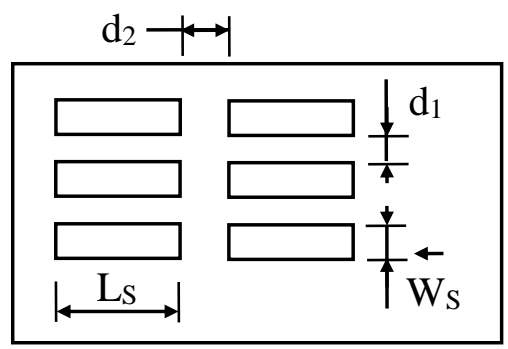

Fig. (3): An elevation view of screen to calculate the coefficient of opening.

The sieves were made from steel sheet metal of $1.5 \mathrm{~mm}$ thickness with drilled oblong holes. The sieve was $500 \mathrm{~mm}$ long, $350 \mathrm{~mm}$ wide. By using try and error method in equation (3), $\mathrm{d}_{1}$ and $\mathrm{d}_{2}$ were calculated taking in account that Co equals $40 \%$. Table (3) shows the characteristics of the sieves.

Table (3): Characteristics of the sieves.

\begin{tabular}{ccccccc}
\hline & $\mathrm{L}_{\mathrm{s}}$ & $\mathrm{W}_{\mathrm{s}}$ & $\mathrm{d}_{1}$ & $\mathrm{~d}_{2}$ & $\mathrm{n}_{1}$ & $\mathrm{n}_{2}$ \\
\hline Upper sieve & 25 & 10 & 8 & 8 & 15 & 20 \\
Lower sieve & 20 & 8 & 7 & 6 & 16 & 20 \\
\hline
\end{tabular}

\subsubsection{Sieve mechanism}

The screens were fixed inside screen casing which is suspended by hangers. They consist of upper and lower sieves and hang on four links ( 2 adjustable rods in the front and 2 fixed in the rear to alter the sieve tilt angle $-250 \mathrm{~mm}$ length). Bolts and nuts were used to fasten them together 
to make it detachable. The tilt angle can be varied from 0 to $30^{\circ}$ (Fig. 2). The crank mechanism was used to produce the reciprocating motion of sieve. Radius of crank is $50 \mathrm{~mm}$ and connecting rod is $300 \mathrm{~mm}$ long.

Design crank mechanism: A vibrated sieve is used to grade garlic cloves. Agitation of the sieve results in displacement of the garlic clove over its surface. The garlic cloves should be so agitated that separation is optimal. The garlic cloves should be uniformly distributed over the sieve surface and moved towards the delivery end of the sieve. The resultant force on a particle must be higher than the friction force between the garlic cloves and the surface. Particle velocity on the sieve surface must not be too high, or the garlic cloves will pass by the sieve openings instead of falling through. The sieve is agitated by multiple system linkage taking in consideration the kinematics characteristics of linear motion that are given by the following (klenin et al, 1985):

$$
\begin{gathered}
\mathrm{X}=\mathrm{r}(1-\cos \omega \mathrm{t}) \\
\bar{X}=\omega \mathrm{r} \sin \omega \mathrm{t} \\
\bar{X}=\omega^{2} \mathrm{r} \cos \omega \mathrm{t}
\end{gathered}
$$

Where

$X \quad$ : Instantaneous displacement (m).

$\bar{X} \quad: \quad$ Motion velocity $\left(\mathrm{m} \mathrm{s}^{-1}\right)$.

$X^{-} \quad$ : Acceleration of motion $\left(\mathrm{m} \mathrm{s}^{-2}\right)$.

$\omega:$ : Angular velocity $\left(\mathrm{rad} \mathrm{s}^{-1}\right)$.

$\mathrm{r} \quad$ : Crank shaft length (m).

\section{The following forces acting on a sieve due to garlic cloves:}

1- Force due to the weight $(W=\mathrm{m} g)$ of the garlic cloves directed downward.

2-Inertia force $\left(F_{i}\right)$ acting in a direction opposite to that of the mass acceleration force (a force due to inertia in the opposite direction of acceleration). The magnitude of the force $F_{i}$ is obtained as follows:

$$
\mathrm{F}_{\mathrm{i}}=\mathrm{m} \stackrel{-}{X}=\mathrm{m} \omega^{2} \mathrm{r} \cos \omega \mathrm{t}
$$

Where

m : Mass of garlic cloves.

g : Gravity acceleration. 
3- Friction force $\left(F_{f}\right)$ between the garlic cloves and the sieve surface acting in a direction opposite to motion direction.

4- Reaction force $(R)$ of the working surface on the garlic cloves acting in a direction normal to the surface.

The sieve is set horizontal or inclined to the horizontal plane, the angle of inclination selected from the condition $\alpha \leq \phi$

Where

$\alpha \quad$ : Angle of sieve with the horizontal.

$\phi \quad: \quad$ Friction angle between the garlic cloves and the sieve surface.

According to the condition given above, the material will not slide over the sieve when it is stationary. When the sieve is agitated at a particular frequency and amplitude, a motion is imported to the material relative to the sieve surface. The possible type of motion of the material is only sliding motion over the sieve towards the delivery end, and in the reverse direction or loss of all contact between the material and the sieve surface.

Motion of material over the sieve surface at the delivery end from $A$

to B: Motion at the delivery end is possible when the resultant of all forces acting the material is greater than the friction force (Fig.4):

$$
\begin{gathered}
\mathrm{W} \sin \alpha+\mathrm{F}_{\mathrm{i} \cdot} \cos \alpha \geq \mathrm{F}_{\mathrm{f}} \\
\mathrm{F}_{\mathrm{f}}=\mathrm{R} \tan \phi=\mu \mathrm{R}
\end{gathered}
$$

Where

$\mu \quad$ : Coefficient of friction.

To determine force $(\mathrm{R})$ projecting all the forces in a direction normal to the sieve:

$$
\mathrm{R}=\mathrm{W} \cos \alpha-\mathrm{F}_{\mathrm{i}} \sin \alpha
$$

Then motion of the garlic cloves at the exit may be expressed by the following inequality:

$\mathrm{W} \sin \alpha+\mathrm{F}_{\mathrm{i}} \cos \alpha \geq \mu \mathrm{W} \cos \alpha-\mu \mathrm{F}_{\mathrm{i}} \sin \alpha$ $\mathrm{mg} \sin \alpha+\mathrm{m} \omega^{2} \mathrm{r} \cos \alpha \geq \mu \mathrm{mg} \cos \alpha-\mu \mathrm{m} \omega^{2} \mathrm{r} \sin \alpha$

$$
\begin{aligned}
& \omega_{1}=\sqrt{\frac{g(\mu \cos \alpha-\sin \alpha)}{r(\cos \alpha+\mu \sin \alpha)}}, \operatorname{rad~s}^{-1} \\
& \mathrm{~N}_{1}=\frac{60}{2 \pi} \sqrt{\frac{\mathrm{g}(\mu \cos \alpha-\sin \alpha)}{\mathrm{r}(\cos \alpha+\mu \sin \alpha)}}, \mathrm{rpm}
\end{aligned}
$$




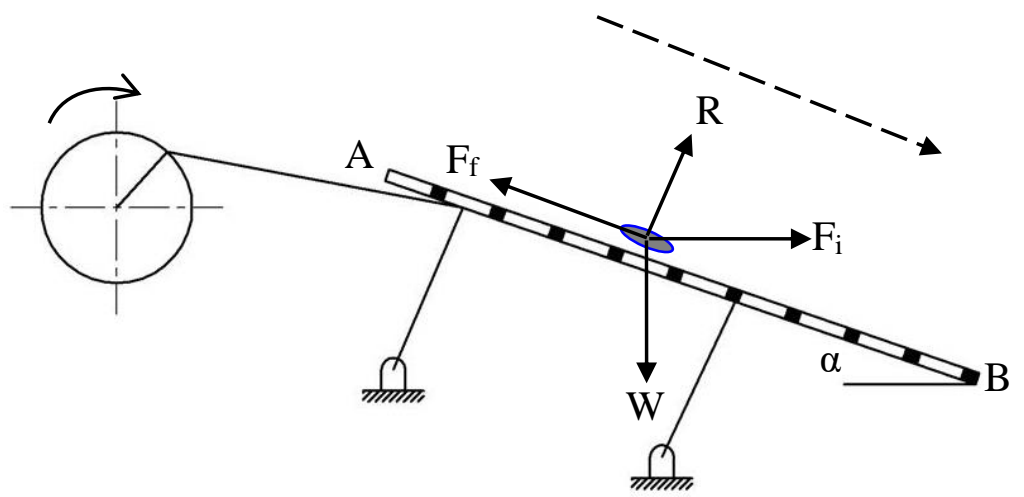

Fig. (4): Motion of material over the sieve surface at the delivery end from $A$ to $B$.

Sliding motion of the material up and down the sieve surface from $B$ to A: Fig. (5) shows the movement of material from B to A is possible when:

Where

$$
\begin{aligned}
& F_{i} \cos \alpha-W \sin \alpha \geq F_{f} \\
& R=W \cos \alpha+F_{1} \sin \alpha
\end{aligned}
$$

Then the motion of material in this case may be expressed by the following inequality:

$\mathrm{F}_{\mathrm{i}} \cos \alpha-\mathrm{W} \sin \alpha \geq \mu \mathrm{W} \cos \alpha+\mu \mathrm{F}_{\mathrm{i}} \sin \alpha$ $\mathrm{m} \omega^{2} \mathrm{r} \cos \alpha-\mathrm{mg} \sin \alpha \geq \mu \mathrm{mg} \cos \alpha+\mu \mathrm{m} \quad \omega^{2} \mathrm{r} \sin \alpha$

$$
\begin{aligned}
\omega_{2} & =\sqrt{\frac{g(\mu \cos \alpha+\sin \alpha)}{r(\cos \alpha-\mu \sin \alpha)}}, \mathrm{rad} \mathrm{s}^{-1} \\
N_{2} & =\frac{60}{2 \pi} \sqrt{\frac{g(\mu \cos \alpha+\sin \alpha)}{r(\cos \alpha-\mu \sin \alpha)}}, \mathrm{rpm}
\end{aligned}
$$

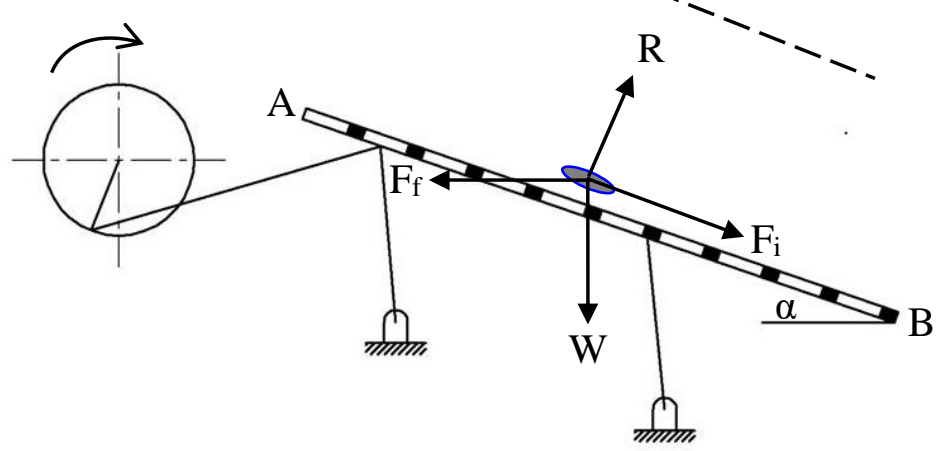

Fig. (5): Sliding motion of the material up and down the sieve surface from $B$ to $A$. 
Sieving and separating are more successful under the following conditions: $\mathrm{N}>\mathrm{N}_{2}$ and $\mathrm{N}_{2}>\mathrm{N}_{1}$.

Where

$\mathrm{N} \quad$ : the optimum sieve speed (rpm).

Under the above conditions and by using the previous equations the separator was adjusted as follows:

1- Angle of sieve $(\alpha)$ with the horizontal is determined to be less than the friction angle $(\phi)$ between the garlic cloves and the sieve surface $(\phi=\tan \mu), \therefore \alpha \leq 34$ deg.

2- Sieve motion was adjusted from an eccentric with a radius of $50 \mathrm{~mm}$.

3- $\mathrm{N}_{1}$ and $\mathrm{N}_{2}$ were calculated from the above equations with the angle of sieve from 0 to $34 \mathrm{deg}$. The maximum values were 109.84 and 172.53 rpm respectively, so optimum sieve speed was calculated to be as follows

$\mathrm{N} \geq 172.53 \mathrm{rpm}$.

The machine will be evaluated at three levels of crank speed: 200, 225, 250 and $275 \mathrm{rpm}$.

Power transmission by V-belts and pulley was according to Khurmi and Gupta (2005):

$$
\mathrm{N}_{\mathrm{s} 1} \mathrm{D}_{1}=\mathrm{N}_{\mathrm{s} 2} \mathrm{D}_{2}
$$

Where

$\mathrm{N}_{\mathrm{s} 1}, \mathrm{~N}_{\mathrm{s} 2}$ : Speeds of driving and driven pulleys respectively (rpm).

$\mathrm{D}_{1}, \mathrm{D}_{2}$ : Diameters of driving and driven pulleys respectively (mm).

Substituting the required speeds at the crank shaft $\mathrm{N}_{1}$ are 200, 225, 250 and $275 \mathrm{rpm}$, knowing the rated speed of the electric motor $\left(\mathrm{N}_{2}=70\right.$ $\mathrm{rpm}), \mathrm{D}_{1}$ and $\mathrm{D}_{2}$ were calculated as shown in table (4).

Table (4): The values of $D_{1}$ and $D_{2}$.

\begin{tabular}{lccccc}
\hline & \multicolumn{2}{c}{ Pulley of machine } & & \multicolumn{2}{c}{ Pulley of motor } \\
\cline { 2 - 3 } \cline { 5 - 6 } & $\mathrm{N}_{\mathrm{s} 1}(\mathrm{rpm})$ & $\mathrm{D}_{1}(\mathrm{~mm})$ & & $\mathrm{N}_{\mathrm{s} 2}(\mathrm{rpm})$ & $\mathrm{D}_{2}(\mathrm{~mm})$ \\
\hline $1 \mathrm{st}$ & 200 & 105 & & 70 & 300 \\
$2 \mathrm{nd}$ & 225 & 93 & & 70 & 300 \\
$3 \mathrm{rd}$ & 250 & 84 & & 70 & 300 \\
$4 \mathrm{th}$ & 275 & 76 & & 70 & 300 \\
\hline
\end{tabular}




\subsubsection{Power requirement}

Theoretical power requirement for oscillation can be approximately calculated by summation of power required for the movement in the vertical and horizontal directions (Okunola and Igbeka, 2009).

For vertical,

$$
H p_{1}=\frac{2 \cdot W_{S C} \cdot N \cdot Y}{4500}
$$

For horizontal,

$$
H p_{2}=\frac{2 \cdot W_{S C} \cdot N \cdot X \cdot \mu_{h}}{4500}
$$

Where

$\mathrm{W}_{\mathrm{SC}} \quad$ : Weight of reciprocating unit along with garlic cloves on it (it was determined $=25 \mathrm{~kg}$ ).

$\mathrm{N}$ : Speed in rpm, (275 rpm was used).

Y : Vertical displacement of the reciprocating assembly per stroke, (it was determined from the drawing $=0.0046 \mathrm{~m}$ ).

$\mathrm{X}$ : Horizontal displacement of reciprocating assembly per stroke, (it was determined from the drawing $=0.095 \mathrm{~m}$ ).

$\mu_{\mathrm{h}} \quad$ : Coefficient of friction between hinge points $(0.3)$

Total power for oscillation was $0.1 \mathrm{Hp}(0.075 \mathrm{~kW})$, adding $20 \%$ for safe performance, so the required power is $0.12 \mathrm{Hp}(0.09 \mathrm{~kW})$.

\subsubsection{Cleaning unit}

Aerodynamic properties separate the stems, leaves, and chaff from the garlic cloves. Either a fan or blower fan can be chosen to propel the air. Fan selection depends upon terminal velocities of garlic cloves, chaff, leaves, and stem (Table 2). The air velocity needed to separate the stems and leaves from garlic cloves were $1.37-2.44 \mathrm{~m} \mathrm{~s}^{-1}$, greater than the terminal velocity of the garlic cloves. A centrifugal fan with straight blades was used with an airflow rate of $0.4 \mathrm{~m}^{3} \mathrm{~s}^{-1}$ to supply an airflow velocity of up to $2.5 \mathrm{~m} \mathrm{~s}^{-1}$.

A air stream is supplied by a centrifugal blower operated by an electric motor of $0.65 \mathrm{~kW}$ with $\mathrm{V}$-shape belt bully. The blower has 6 straight blade impeller with a square duct .The duct is placed over the outlet of the blower. The air going out by the blower moves through the duct and separates the light particles (straw and chaff) from the garlic cloves. The air velocity over the upper sieve was kept less than the terminal velocity 
of the garlic cloves. Airflow channel outlet has a $330 \mathrm{~mm}$ by $300 \mathrm{~mm}$ rectangular outlet. The air velocity was measured using tri-Sence digital instrument connected with a velocity probe

\subsection{Performance evaluation}

The developed machine was evaluated at four different levels of crank speeds, four levels of feed rate and three levels of sieve tilt angle (Table 5 ). The performance of grading mechanisms was possibly measured by grading efficiency, machine capacity and consumed energy were evaluated at each combination of variables.

Feeding rate levels were chosen according to the optimal operating value of separating unit for garlic cloves, which is the machine capacity of separating unit.

Table (5): Experimental values of performance parameter for evaluation modified machine.

\begin{tabular}{ll}
\hline Variables & Levels \\
\hline Crank speed sieve oscillation, $\mathrm{C}_{\mathrm{S}}(\mathrm{rpm})$ & $200,225,250,275$ \\
Feed rate, $\mathrm{F}_{\mathrm{R}}\left(\mathrm{kg} \mathrm{h}^{-1}\right)$ & $233,266,326,353$ \\
Sieve tilt angle, $\mathrm{S}_{\mathrm{A}}(\mathrm{deg})$ & $5,10,20$ \\
\hline
\end{tabular}

\subsubsection{Grading capacity $\left(\boldsymbol{P}_{m}\right)$}

Time of grading process was measured by means of a stop watch, the capacity of the machine was calculated as follows:

$$
\mathrm{P}_{\mathrm{m}}=\frac{\mathrm{W}}{\mathrm{T}}
$$

Where

$\mathrm{P}_{\mathrm{m}} \quad$ : The grading capacity $\left(\mathrm{kg} \mathrm{h}^{-1}\right)$.

$\mathrm{W}$ : The mass of sample $(\mathrm{kg})$.

$\mathrm{T}$ : Grading time (hour).

\subsubsection{Grading efficiency $(G E)$}

A vernier caliper with a resolution of $0.01 \mathrm{~mm}$ was used to measure the linear cloves dimensions for each outlet. The ratio of well-classified cloves to total number of cloves for the same outlet was computed. The grading efficiency of the outlet was calculated according to the following equation (Mostafa and Bahnasawy, 2009): 


$$
\eta_{1}=\frac{\mathrm{n}_{\mathrm{Cl}}}{\mathrm{N}_{\mathrm{C}}}
$$

Where

$\eta_{1}: \quad$ The grading efficiency (\%).

$\mathrm{n}_{\mathrm{C} 1}: \quad$ The number of the well-classified cloves for an outlet.

$\mathrm{N}_{\mathrm{C}}$ : The total number of cloves passing through the metering gap of the considered outlet.

The total efficiency of the machine was calculated as the average of the efficiencies of each category using the following equation:

$$
\eta_{\text {Total }}=\frac{\eta_{1}+\eta_{2}+\eta_{3}}{3}
$$

Where

$\eta_{\text {Total }}:$ The total grading efficiency of the machine (\%).

$\eta_{1}, \eta_{2}, \eta_{3}:$ The efficiencies of the classified cloves for first, second, and third outlet respectively.

\subsubsection{Consumed energy $(C E)$}

The required electric power was measured for cleaning and grading process. The required electric power was calculated as Chancellor (1981) by the following equation:

$$
\mathrm{RP}=\mathrm{V} \times \mathrm{I} \times \cos \theta
$$

Where

RP : The required power (W).

V : $\quad$ Potential difference, Voltage (I phase $=220$ voltage).

I : Line current strength (Amperes).

$\cos \theta:$ Power factor, equal 0.64 .

A digital clamp meter and Voltmeter were used for measuring current intensity and voltage respectively.

The consumed energy $(C E)$ is specific energy requirements per unit output; it was calculated by using the following equation:

Consumed energy $=\left(\mathrm{RP} / \mathrm{P}_{\mathrm{m}}\right), \mathrm{kW} \mathrm{h}$ ton $^{-1}$

\subsubsection{Costs}

Grading and cleaning cost was determined using the fixed costs (deprecation, interest on investment, housing, insurance, and taxes) and variable costs 
(repair and maintenance, electricity, and labor) according to Srivastava et al. (2006). The price of grading and cleaning units was 2000 L.E. The unit cost was determined using the following equation:

$$
\text { Unit cost }=\frac{\text { Grading and cleaning costs }\left(\mathrm{L} \cdot \mathrm{E} \mathrm{h}^{-1}\right)}{\text { Grading capacity }\left(\text { ton }^{-1}\right)}, \text { L.E ton }{ }^{-1}
$$

\section{RESULTS AND DISCUSSIONS}

Table (6) shows mean values of grading efficiency and grading capacity at different crank speeds, feeding rates and sieve angles.

Table (6): Performance parameters of machine at different crank speeds, feeding rates and sieve angles.

\begin{tabular}{|c|c|c|c|c|c|c|c|}
\hline \multirow{3}{*}{$\begin{array}{l}\text { Crank } \\
\text { speed } \\
\text { (rpm) } \\
\end{array}$} & \multirow{3}{*}{$\begin{array}{c}\text { Feeding } \\
\text { rate } \\
\left(\mathrm{kg} \mathrm{h}^{-1}\right) \\
\end{array}$} & \multicolumn{3}{|c|}{$\begin{array}{c}\text { Grading efficiency } \\
(\%)\end{array}$} & \multicolumn{3}{|c|}{$\begin{array}{l}\text { Grading capacity } \\
\qquad\left(\mathrm{kg} \mathrm{h}^{-1}\right)\end{array}$} \\
\hline & & \multicolumn{3}{|c|}{ Sieve angle (deg.) } & \multicolumn{3}{|c|}{ Sieve angle (deg.) } \\
\hline & & $5^{\circ}$ & $10^{\circ}$ & $20^{\circ}$ & $5^{\mathbf{0}}$ & $10^{\circ}$ & $20^{\circ}$ \\
\hline \multirow{4}{*}{200} & 233 & 90.6 & 96.6 & 96.1 & 116.5 & 121.16 & 125.82 \\
\hline & 266 & 88.8 & 92.9 & 95.5 & 154.28 & 159.6 & 159.6 \\
\hline & 326 & 88.4 & 92.4 & 93.8 & 192.34 & 198.86 & 198.86 \\
\hline & 353 & 85.7 & 89.9 & 89.8 & 218.86 & 218.86 & 222.39 \\
\hline \multirow{4}{*}{225} & 233 & 97.8 & 97.3 & 96 & 142.13 & 144.46 & 146.79 \\
\hline & 266 & 94.4 & 94.2 & 97 & 167.58 & 170.24 & 172.9 \\
\hline & 326 & 93 & 94.3 & 95 & 205.38 & 257.54 & 254.28 \\
\hline & 353 & 86.9 & 91.2 & 92.2 & 229.45 & 275.34 & 275.34 \\
\hline \multirow{4}{*}{250} & 233 & 97.1 & 97.6 & 96.6 & 165.43 & 177.08 & 177.08 \\
\hline & 266 & 95.5 & 94.3 & 96.9 & 199.5 & 212.8 & 215.46 \\
\hline & 326 & 94.7 & 94.9 & 94.4 & 267.32 & 270.58 & 283.62 \\
\hline & 353 & 91.6 & 90.3 & 89.7 & 292.99 & 303.58 & 307.11 \\
\hline \multirow{4}{*}{275} & 233 & 87.6 & 87.7 & 82 & 209.7 & 209.7 & 209.7 \\
\hline & 266 & 86.6 & 84.3 & 88.2 & 242.06 & 242.06 & 244.72 \\
\hline & 326 & 83.9 & 87.9 & 82.4 & 296.66 & 299.92 & 303.18 \\
\hline & 353 & 77.6 & 77.3 & 77.1 & 324.76 & 328.29 & 335.35 \\
\hline
\end{tabular}

\subsection{Grading efficiency (GE)}

The grading efficiency ranged from $77.1 \%$ to $97.8 \%$ with crank speed of 200 to $275 \mathrm{rpm}$, sieve angle of $5^{\circ}$ to $20^{\circ}$ and the feeding rate of 233 to $353 \mathrm{~kg} \mathrm{~h}^{-1}$ (Table 6). The results are plotted in Fig. (6). It could be 
noticed that the lowest values of grading efficiency were obtained at $\left(C_{S}\right)$ $275 \mathrm{rpm}$ and $\left(F_{R}\right) 353 \mathrm{~kg} \mathrm{~h}^{-1}$, however the highest values of grading efficiency were obtained at $\left(C_{S}\right) 200 \mathrm{rpm}$ and $\left(F_{R}\right) 233 \mathrm{~kg} \mathrm{~h}^{-1}$ at different sieve angle (Table 6).

As shown in Fig. (6), as the crank speed increased from 200 to $250 \mathrm{rpm}$ the grading efficiency increased. These results may be due to increasing sieve oscillating that facilitate the material to pass through the sieve opening, but with increasing crank speed to $275 \mathrm{rpm}$ the grading efficiency decreased due to that the material was forced to pass over the sieve to outlet.

From Fig. (6), it was found that the grading efficiency decreased as the feed rate increased at different sieve angles. Also, as the sieve angle increased from 5 to 10 degrees the grading efficiency increased. But increasing this angle to 20 degrees decreased the grading efficiency due to that the material rolling over the sieve to outlet.

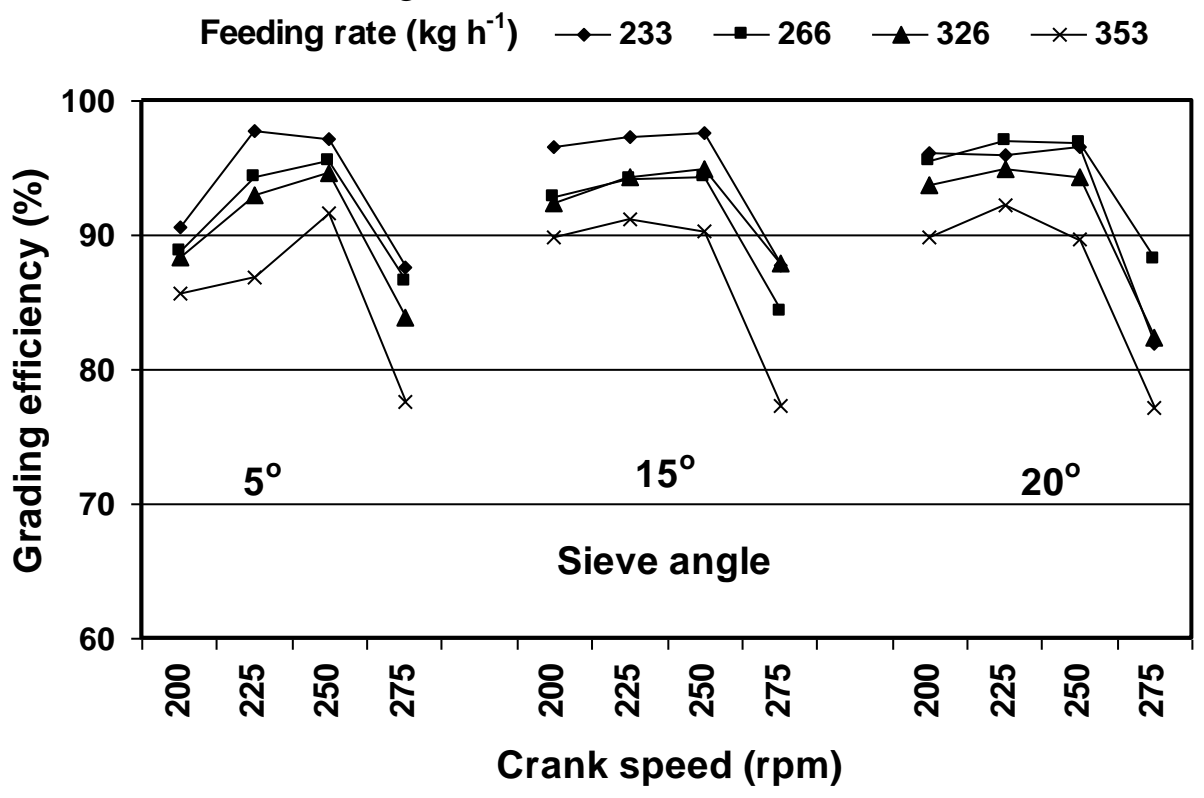

Fig. (6): The effects of crank speed, sieve angle and feeding rate on the grading efficiency.

\subsection{Grading capacity $\left(\mathbf{P}_{\mathrm{m}}\right)$}

The grading capacity ranged from 116.5 to $335.35 \mathrm{~kg} \mathrm{~h}^{-1}$ with crank speed of 200 to $275 \mathrm{rpm}$, sieve angle of $5^{\circ}$ to $20^{\circ}$ and the feeding rate of 
233 to $353 \mathrm{~kg} \mathrm{~h}^{-1}$ (Table 6). The results are plotted in Fig. (7). It could be noticed that the lowest values of grading capacity were obtained at $\left(C_{S}\right)$ $200 \mathrm{rpm}$ and $\left(F_{R}\right) 233 \mathrm{~kg} \mathrm{~h}^{-1}$, however the highest values of grading efficiency were obtained at $\left(C_{S}\right) 275 \mathrm{rpm}$ and $\left(F_{R}\right) 353 \mathrm{~kg} \mathrm{~h}^{-1}$ at different sieve angles (Table 6).

As shown in Fig. (7), as the crank speed decreased, the grading capacity increased. These results may be due to increasing of oscillating movement of sieve that facilitated the material to pass through the opening sieve.

From Fig. (7), it was found that the grading capacity increased as the feed rate increased at different sieve angles. Also by increasing the sieve angle the grading capacity increased.

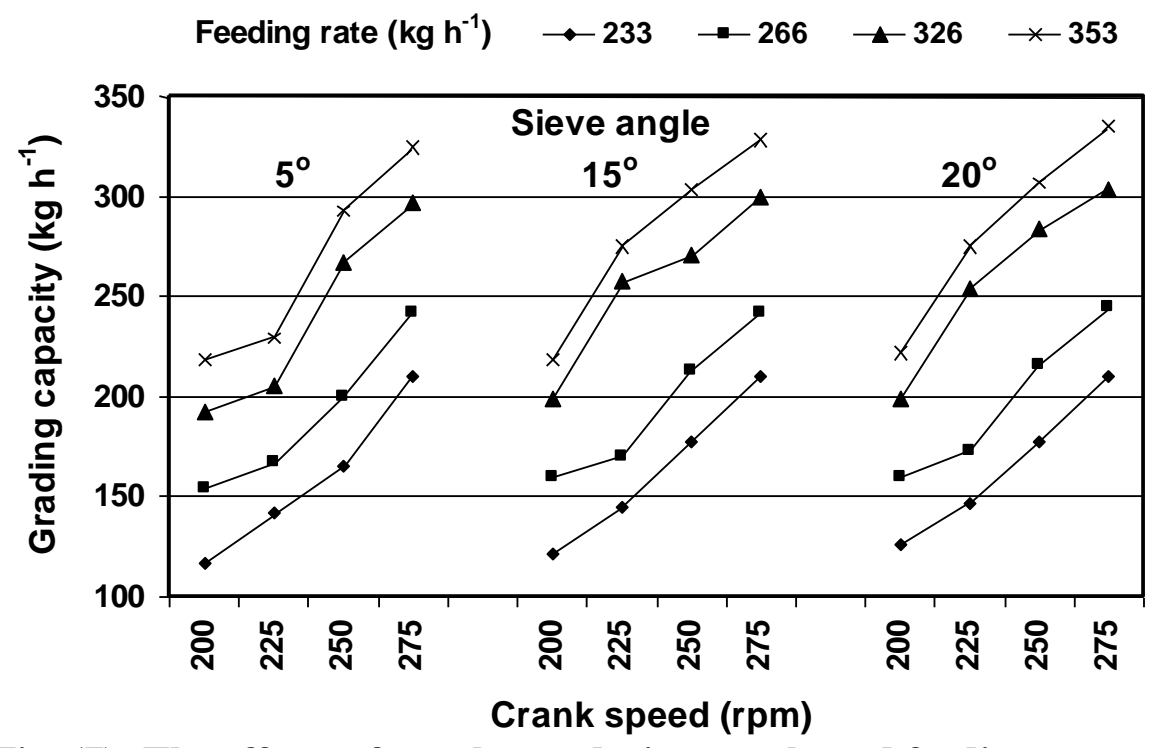

Fig. (7): The effects of crank speed, sieve angle and feeding rate on the machine capacity.

\subsection{Consumed energy (CE)}

The consumed energy ranged from 1.85 to $5.32 \mathrm{~kW} \mathrm{~h} \mathrm{ton}{ }^{-1}$ with crank speed of 200 to $275 \mathrm{rpm}$, sieve angle of $5^{\circ}$ to $20^{\circ}$ and the feeding rate of 233 to $353 \mathrm{~kg} \mathrm{~h}^{-1}$ (Table 6). The results are plotted in Fig. (8). It could be noticed that the lowest values of consumed energy were obtained at $\left(C_{S}\right)$ $275 \mathrm{rpm}$ and $\left(F_{R}\right) 353 \mathrm{~kg} \mathrm{~h}^{-1}$, however the highest values of consumed energy were obtained at $\left(C_{S}\right) 200 \mathrm{rpm}$ and $\left(F_{R}\right) 233 \mathrm{~kg} \mathrm{~h}^{-1}$ at different sieve angles (Table 6). 
As shown in Fig. (8), as the crank speed increased, the consumed energy decreased. These results may be due to increasing the grading capacity.

From Fig. (8), it was found that the consumed energy decreased as the feed rate increased at different sieve angles. Also, as the sieve angle increased, the consumed energy decreased.

From table (6), the most suitable conditions for machine realizing the best performance that take the best grading efficiency value of $86.9 \%$ $97.8 \%$ were observed at combination of crank speed $=225 \rightarrow 250 \mathrm{rpm}$; sieve angle $=5 \rightarrow 20$ degree at different feeding rates.

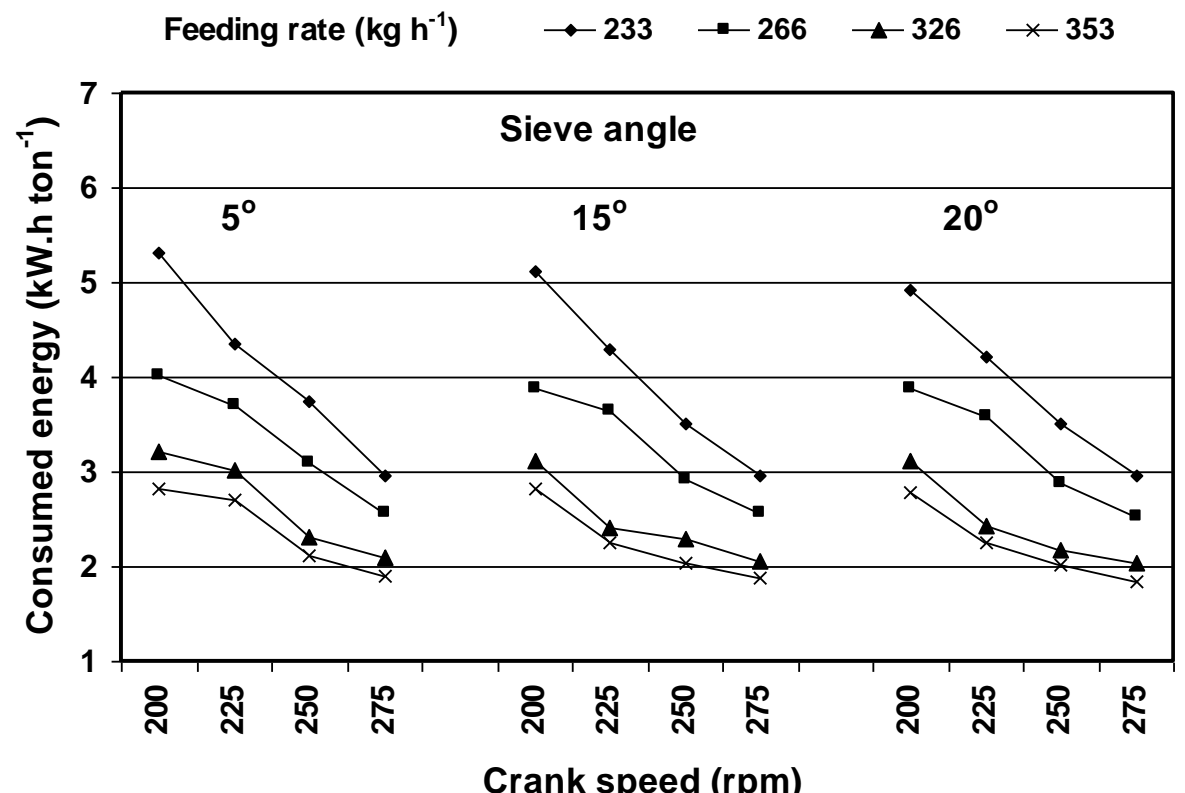

Fig. (8): The effects of crank speed, sieve angle and feeding rate on consumed energy.

\subsection{Costs}

According to the suitable conditions for machine, the grading capacity ranged from 142.1 and $307.1 \mathrm{~kg} \mathrm{hr}^{-1}$. Also the grading and cleaning costs

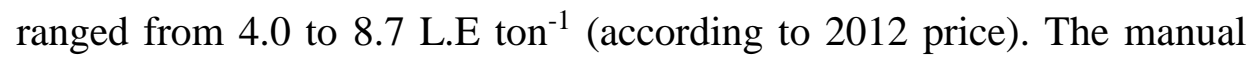
grading capacity and cost are $60 \mathrm{~kg} \mathrm{hr}^{-1}$ and $83.3 \mathrm{L.E} \mathrm{ton}{ }^{-1}$ respectively.

Figure (9) presents a comparison of average value of grading capacity and cost for the machine with the manual method. The capacity increased about 2.7 times and the grading cost reduction of $93 \%$ compared with manual method. 


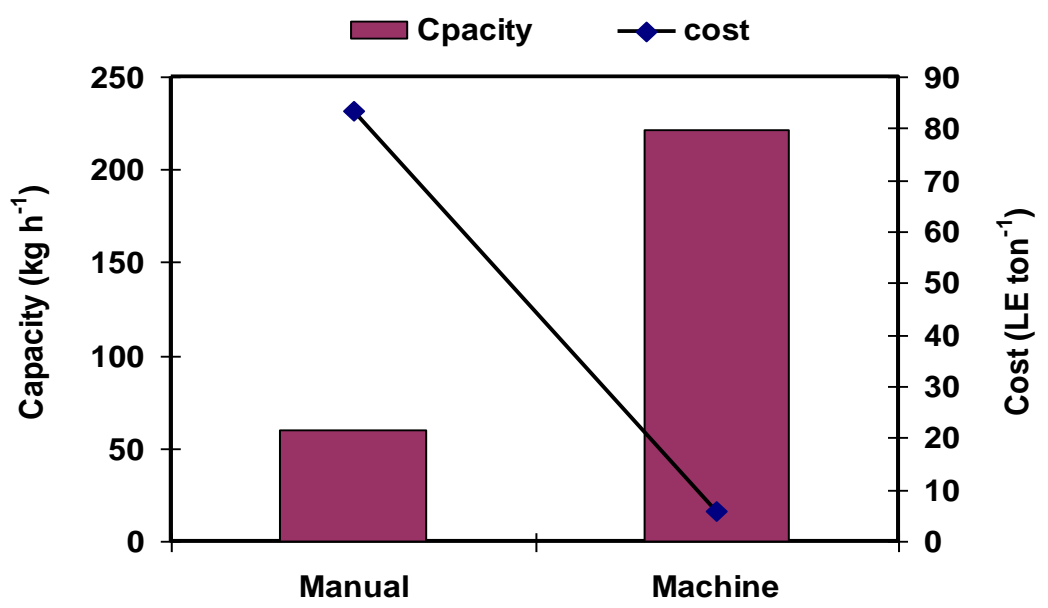

Fig. (9): Capacity and cost of grading with different methods.

\subsection{Regression models for the performance parameters}

The obtained data of table (7) for the crank speed, feeding rate and sieve angle were used as factors affecting the values of grading efficiency, machine capacity and consumed energy. Multiple regression approach (by using SPSS software version 14) was used to derive a regression equation (23).

Where

$$
Y=a . C s+b . F_{R}+c . S_{A}+k
$$

$Y$

: The value of grading efficiency, machine capacity and consumed energy.

$\mathrm{C}_{\mathrm{S}} \quad: \quad$ Crank speed, $\mathrm{rpm} ;\left(200 \leq \mathrm{C}_{\mathrm{S}} \leq 275\right)$.

$\mathrm{F}_{\mathrm{R}} \quad:$ Feeding rate, $\mathrm{kg} \mathrm{h}^{-1} ;\left(233 \leq \mathrm{F}_{\mathrm{R}} \leq 353\right)$.

$\mathrm{S}_{\mathrm{A}} \quad$ : Sieve angle, deg; $\left(5 \leq \mathrm{S}_{\mathrm{A}} \leq 20\right)$

$\mathrm{a}, \mathrm{b}, \mathrm{c} \& \mathrm{k}$ : Empirical constants.

The values of the empirical constants ( $a, b, c$ and $k$ ) and the coefficient of determination $\left(\mathrm{R}^{2}\right)$ of equation (23) are shown in table (7).

Table (7): The empirical constants and the coefficient of determination $\left(\mathbf{R}^{2}\right)$ for the five performance parameters.

\begin{tabular}{lccccc}
\hline \multirow{2}{*}{\multicolumn{1}{c}{$(\mathbf{Y})$}} & \multicolumn{4}{c}{ Empirical constant } & \multirow{2}{*}{$\mathbf{R}^{\mathbf{2}}$} \\
\cline { 2 - 5 } & $\mathbf{a}$ & $\mathbf{b}$ & $\mathbf{c}$ & $\mathbf{k}$ & \\
\hline Grading efficiency, GE $(\%)$ & -0.096 & -0.050 & 0.080 & 127.551 & 0.435 \\
Machine capacity, $\mathbf{P}_{\mathbf{m}}\left(\mathbf{k g ~ h} \mathbf{~ h}^{-\mathbf{1}}\right)$ & 1.303 & 0.962 & 0.778 & -379.89 & 0.975 \\
Consumed energy, $\mathbf{C E}\left(\mathbf{k W . h}\right.$ ton $\left.^{-1}\right)$ & -0.019 & -0.014 & -0.011 & 11.684 & 0.929 \\
\hline
\end{tabular}




\section{CONCLUSION}

The obtained results can be summarized as follows:

1. Crank speed, feeding rate and sieve angle affected the performance of the machine.

2. Grading efficiency increased with the increase of crank speed from 200 to $250 \mathrm{rpm}$ after that decreased, but decreased with increasing in feeding rate and sieve angle.

3. Machine capacity increased with the increase of crank speed, feeding rate and sieve angle.

4. Consumed energy decreased with the increase of crank speed, feeding rate and sieve angle.

5. It is recommended to get the best grading efficiency at combination of crank speed $=225 \rightarrow 250 \mathrm{rpm} /$ sieve angle $=$ $5 \rightarrow 20$ degree at different feeding rate.

6. Using the grading unit increased the grading capacity about 2.7 times and reduced the grading cost but $93 \%$ comparing with manual method.

7. The empirical results were used to introduce a derived mathematical equation to predict the value of machine capacity, grading efficiency and consumed energy as a function of crank speed, feeding rate and sieve angle.

\section{REFERENCES}

Amin, E. E. A. 2003. Effect of some physical and mechanical properties on grading efficiency. The 11th. An. Conf Misr Society of Agr. Eng. (MSAE) Oct.: 451-470.

ASAE Standards. 1999. Moisture measurement - unground grain and seeds. Standard ASAE NO: S352.2 DEC97. St. Joseph, Mich. ASAE:567.

Awady, M. N. and A. S. El Sayed. 1994. Separation of peanut seeds by air stream. Misr J. Ag. Eng. 11 (1): 137-147.

Bahnasawy, A. H. 2007. Some physical and mechanical properties of garlic. Int. J. Food Eng. 3, 1-18.

Castellanos, J. Z., P. Vargas-Tapia, J. L. Ojodeagua and G. Hoyos. 2004. Garlic productivity and profitability as affected by seed cloves size, planting density and planting method. HortSc. Vol. 39 (6): $1272-1277$. 
Chancellor, W. J. 1981. Substituting information for energy in agriculture. Trans. ASAE Paper No. 0001- 2351.

Halling, J. 1975. Principles of Tribology. Printed in Great Britain by Tinling (1973) Ltd, Prescot, Merseyside.

Ibrahim, M. M. 2008. Determination of dynamic coefficient of friction for some materials for feed pellet under different values of pressure and temperature. Misr J. Ag. Eng., 25(4):1389-1409.

Khurmi, R. S. and J. K. Gupta. 2005. Theory of machines. New Delhi: Eurasia Pub. House: 315.

Klenin, N. I., I. F. Popov and V. A. Sakun. 1985. Agricultural Machines: Theory of operation, computation of controlling parameters and the conditions of operation. Amerind publishing co. PVT. LTD. N. Y.

Matlob, A. N. and A. M. Khalel. 1986. Effect of planting dates, plant spacing and clove size on vegetative growth and bulbing of garlic (ALLIUM SATIVUM L.). Iraqi J. Agric. Sc. zanco 4(3): 35-50.

Mohsenin, N. N. 1986. Physical properties of plant and animal materials. Gordon and Breach Sc. Pub., N. Y. : 734.

Mostafa, H. M. and A. H. Bahnasawy. 2009. Development of affordable machine for sizing Egyptian onion. Agr. Eng. I.: the CIGR Ejournal. Manuscript FP 1179. Vol. XI.

Nigrini, O, C. K. Spilman, Y. J. Wang, D. S. Chung, J. L. Steele and E. Posner. 1994. Evaluation of laboratory grain cleaning and separating equpmint. Part II Trans. of the ASAE. 37 (6):1913-1918.

Nourai, A. H. 1994. Effect of planting methods and seed rates on yield, yield components and quality of garlic (ALLIUM SATIVUM L.) in the Sudan. Acta hort. 358: 359-364.

Okunola, A. A. and J. C. Igbeka. 2009. Development of a reciprocating sieve and air blast cereal cleaner. African Crop Sc. Conf. Proc, Vol. 9. : 3 - 8.

Srivastava, A. K., C. E. Goering and R. P. Rohrbach. 2006. Engineering principles of agricultural machines. St. Joseph, Mich.: ASAE: 535-538.

Tabak, S. and D.Wolf. 1998. Aerodynamic properties of cottonseeds. J. Agric. Engng Res. 70:257-265. 


\section{الملخص العربي}

\section{تطوير آلة لتفصيص الثوم: r. جهاز التدريج}

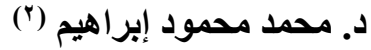 \\ د. عبد الفتاح محمود محمد دريس (1)}

عملية التدريج من العمليات المهمة للذَلات التي تقوم بتفصيص رؤوس الثوم الى فصوص، حيث تم إضافة وحدة خاصة بتدريج وتنظيف فصوص الثوم من أجل إستخدامها فى عمليات الزراعة أو عمليات تصنيعية اخرى، حيث إن الطريقة اليدوية لتدريج الثوم تحتاج إلى مجهود

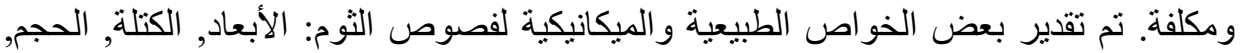
معامل الاحتكالك الاستاتيكى، السرعة الحرجة لفصوص الثوم والمتعلقة بالعمليات الميكانيكية لعمية التدريج والتنظيف واللازمة لعملية التصميم. تم تصميم وتصنيع وحدة التدريج، و التى لتى

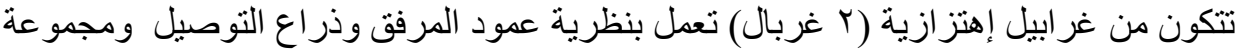

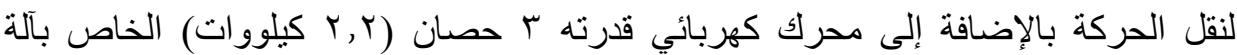

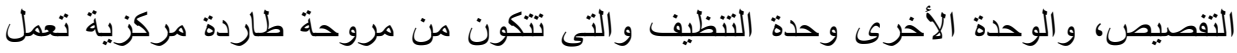

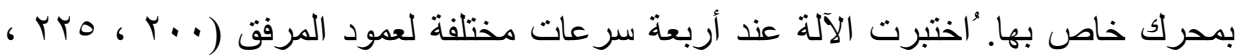

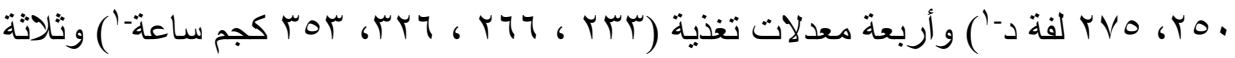

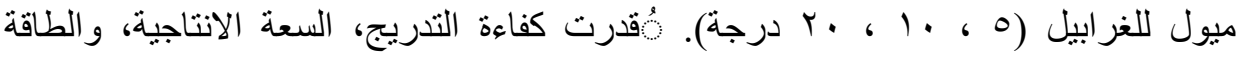
المستهلكة.

\section{وقد بينت الاراسة ما يلي:}

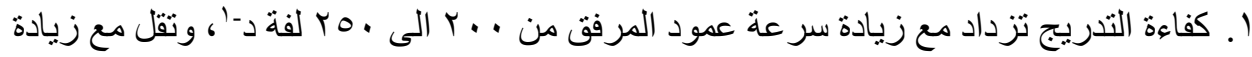
معدل التغذية وميل الغرابيل.

ץ. إنتاجية الآلة تزداد مع زيادة كلا من سرعة عمود المرفق ومعدل التغذية وميل الغر ابيل. ب. الطاقة المستهلكة تقل بزيادة كلا من سر عة عمود المرفق ومعدل التغذية وميل الغر ابيل.

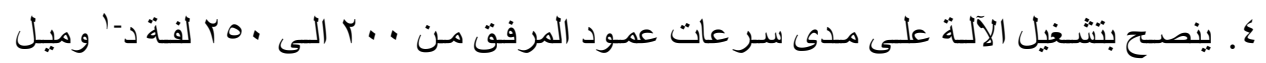

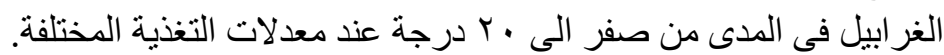

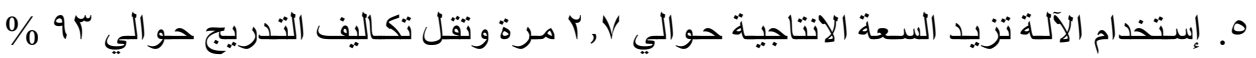
مقارنة بالتدريج اليدوى.

7. تم التوصل الي معادلة بطريقة الإنحدار الخطي بقيم كفاعة تدريج الثوم، السعة الإنتاجيـة للآلة، الطاقة المستهلكة كدالة فى سر عة عمود المرفق ومعدل التغذية وميل الغر ابيل. 